\title{
THE RÔLE OF CUMULUS CELLS AND SERUM IN MOUSE OOCYTE MATURATION IN VITRO
}

\author{
P. G. GROSS \\ Laboratory of Reproductive Physiology, Department of Animal Biology, \\ School of Veterinary Medicine, University of Pennsylvania, \\ Philadelphia, Pennsylvania 19104, U.S.A.
}

(Received 19th Fune 1972)

\begin{abstract}
Summary. Mouse oocytes were matured in vitro with or without cumulus cells and in medium containing non-dialysable or dialysable serum fractions. The criterion for successful maturation of the oocytes was the formation of two-cell embryos after fertilization in vitro. The data demonstrated that (1) cumulus cells do not improve oocyte maturation and subsequent fertilization in vitro and (2) the large molecular weight fraction of serum is the critical component of the system involving maturation in vitro.
\end{abstract}

\section{IN'TRODUCTION}

In a prior investigation, it was shown that mouse oocytes matured in vitro could be fertilized in vitro and that the resulting two-cell ova were capable of developing into viable 15-day-old fetuses (Cross \& Brinster, 1970). It was also shown that the presence of serum in the culture medium during oocyte development improved the subsequent survival of the oocytes. This study did not include an investigation of the nature of the contribution made by serum, but we did observe that cumulus cells adhered more tightly to oocytes cultured in serum than to oocytes cultured without serum. This observation suggested that serum might have its effect by way of the cumulus cells.

The experiments reported here clarify the rôle of serum in oocyte maturation by ( 1 ) investigating the significance of a serum-induced interaction between the oocyte and cumulus cells and (2) determining which serum fraction benefits oocyte maturation.

\section{MATERIALS AND METHODS}

Oocytes were obtained from adult random-bred Swiss mice (Taconic Farms, Inc., Germantown, New York) injected $48 \mathrm{hr}$ previously with 5 i.u. PMSG (Equinex, Ayerst). Electron microscopic studies (Merchant \& Chang, 1971) and our personal observations have shown that this injection of PMSG does not stimulate any morphological changes in the oocyte. It is used in this study to increase the number of oocytes with adhering cumulus cells. Antral follicles were punctured (Donahue, 1968) and fully grown immature oocytes with intact germinal vesicles were selected for culture (Cross \& Brinster, 1970). 
When follicles are punctured, some of the immature oocytes released have a few layers of tightly adhering cumulus cells whereas other immature oocytes have no attached cumulus cells. These oocytes are referred to in the text as 'surrounded' and 'absent', respectively. In one of the experiments, the cumulus surrounding the oocytes was removed by using a pipette just slightly larger than the oocyte diameter (hyaluronidase was not used). Cumulus cells removed in this way were either left in the drop with the denuded oocytes or removed from the drop. These oocytes are referred to as 'removed-present' and 'removedabsent', respectively.

All oocytes were cultured in vitro for $18 \mathrm{hr}$ in drops of medium under Silicone fluid at $37^{\circ} \mathrm{C}$ in an atmosphere of $5 \% \mathrm{CO}_{2}$ in air (Brinster, 1963). Components of the culture medium varied with each experiment but the part of the medium referred to in the text as 'Simple' (S) was basic to all media and consisted of a Krebs-Ringer bicarbonate-buffered solution containing 0.50 mm-sodium pyruvate and 5.56 mm-glucose as energy sources (Cross \& Brinster, 1970). This S medium was extended with either $30 \mathrm{mg} / \mathrm{ml}$ bovine serum albumin (BSA, Miles) $(\mathrm{S}+\mathrm{BSA}), 15 \%$ whole calf serum (Gibco) $(\mathrm{S}+$ serum), $15 \%$ nondialysable serum ( $\mathrm{S}+$ non-dialysable serum) or $15 \%$ dialysable serum plus 30 $\mathrm{mg} / \mathrm{ml} \mathrm{BSA}$ (S+dialysable serum + BSA). It was necessary to adjust the $\mathrm{pH}$ to $7 \cdot 4$ with $1 \mathrm{~N}-\mathrm{NaOH}$ when $30 \mathrm{mg} / \mathrm{ml}$ protein was added to the medium.

The non-dialysable serum fraction was obtained by placing whole calf serum inside a dialysis bag and twenty times its volume of $\mathrm{S}$ medium outside the bag. The solution, maintained at $4^{\circ} \mathrm{C}$, was gassed with $5 \% \mathrm{CO}_{2}$ in air and continually agitated. Three changes of the external solution, $48 \mathrm{hr}$ apart, ensured the practical elimination of small molecules from the serum. To obtain the dialysable fraction, the same procedure was used with serum as the external solution and S+BSA medium inside the dialysis bag. A starch gel of the dialysable fraction did not reveal any proteins.

In all of the experiments in this study, the criterion for successful development was the number of two-cell embryos resulting from fertilization in vitro. The technique, originally developed by Whittingham (1968), has been previously used to test the extent of normal oocyte maturation (Cross \& Brinster, 1970). The medium is identical to the S+BSA used for maturation except for the addition of $25 \mathrm{~mm}$-sodium lactate. Briefly, the technique consists of placing mature oocytes (either with or without cumulus cells, depending upon the experiment) with spermatozoa stripped from the uteri of a recently mated female. The oocytes and spermatozoa are incubated together for $26 \mathrm{hr}$ and then the number of two-cell embryos is counted. Only two-cell embryos with equal blastomeres and one nucleus/cell were considered normal.

Significance was determined by using the analysis of variance after transforming the results into angles (Biggers \& Brinster, 1965). Individual treatments were compared using the J. W. Tukey method (Snedecor, 1956).

\section{RESULTS}

The first experiments were designed to investigate the rôle, if any, which the cumulus cells have in the effect of serum on maturation. The results of these 
experiments are presented in Table 1 and demonstrate no significant difference between the fertilizability of oocytes matured with or without cumulus cells. Thus, cumulus cells are not a necessary intermediate in the effect of serum on the oocyte.

In addition to the absence of an effect of cumulus cells on oocyte maturation in vitro, we found no significant beneficial effect at fertilization. As shown in

Table 1. Fertilization in vitro of mouse oocytes matured with and without cumulus cells

\begin{tabular}{|c|c|c|c|}
\hline $\begin{array}{c}\text { Type of } \\
\text { cumulus-oocyte } \\
\text { relationship } \\
\text { during maturation* }\end{array}$ & 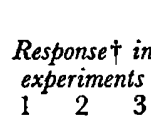 & $\begin{array}{l}\text { Mean } \\
\text { angular } \\
\text { response }\end{array}$ & $\begin{array}{c}\text { Response } \\
(\%)\end{array}$ \\
\hline $\begin{array}{l}\text { Surrounded } \\
\text { Removed-present } \\
\text { Removed-absent } \\
\text { Absent }\end{array}$ & $\begin{array}{lll}4 & 5 & 6 \\
5 & 2 & 7 \\
4 & 1 & 9 \\
3 & 2 & 7\end{array}$ & $\begin{array}{l}45 \cdot 0 \\
42 \cdot 8 \\
43 \cdot 1 \\
38 \cdot 9\end{array}$ & $\begin{array}{l}50 \cdot 0 \\
46 \cdot 7 \\
46 \cdot 7 \\
40 \cdot 0\end{array}$ \\
\hline
\end{tabular}

All oocytes were matured in S medium (see text) + serum for $18 \mathrm{hr}$ before fertilization in vitro. The cumulus cells were removed from the 'surrounded' group before fertilization so that all groups were fertilized without cumulus cells.

* For definition of terms, see text.

$\uparrow$ Number of two-cell embryos out of total of ten immature oocytes initially placed in culture.

Table 2. Effect of cumulus cell adherence, induced by serum during maturation, on subsequent fertilization of mouse oocytes in vitro

\begin{tabular}{l|cc|c|c}
\hline \multicolumn{1}{c|}{ Maturation medium } & $\begin{array}{c}\text { Response* in } \\
\text { experiments } \\
1\end{array}$ & 2 & $\begin{array}{c}\text { Mean } \\
\text { angular } \\
\text { response }\end{array}$ & $\begin{array}{c}\text { Response } \\
(\%)\end{array}$ \\
\hline $\begin{array}{c}\text { S+bovine serum albumin (fertilized } \\
\text { with cumulus cells) }\end{array}$ & 1 & 0 & $9 \cdot 69$ & $2 \cdot 5$ \\
$\begin{array}{c}\text { S+serum (fertilized with cumulus } \\
\text { cells) }\end{array}$ & 10 & 9 & 43.57 & 47.5 \\
$\begin{array}{c}\text { S+serum (fertilized without cumulus } \\
\text { cells) }\end{array}$ & 8 & 6 & 36.20 & 35.0 \\
\hline
\end{tabular}

For $\mathbf{S}$ medium, see text. All oocytes were matured with adhering cumulus cells.

* Number of two-cell embryos out of twenty immature oocytes initially placed in culture.

Table 2, the numbers of two-cell embryos were similar when oocytes matured in vitro in $\mathrm{S}+$ serum were fertilized in vitro with (19/40 two-cell embryos) or without (14/40) adhering cells. An analysis of variance of the data in Table 2 also shows that oocytes matured in defined media and fertilized with cumulus cells (1/40 two-cell embryos) are significantly inferior $(P<0.001)$ to oocytes matured in media containing serum and fertilized with $(19 / 40)$ or without (14/40) cumulus cells. 
The specific contribution of serum to maturation was investigated by dialysing serum and comparing the effects of the large and small molecular weight fractions on oocyte maturation. The results presented in Table 3 clearly show that the beneficial effect of serum is due to the large molecules rather than the small molecules. A significantly greater number of oocytes $(P<0.001)$ were fertilized when previously matured in medium containing non-dialysable serum (17/40 two-cell embryos) than when matured in medium containing whole serum $(8 / 40)$, dialysable serum + BSA $(2 / 40)$ or BSA $(4 / 40)$. The data demonstrate that dialysed serum not only replaces the effect of whole serum, but is superior to whole serum.

Table 3. Fertilization in vitro of mouse oocytes matured in different media

\begin{tabular}{|c|c|c|c|c|c|}
\hline Maturation medium & $\begin{array}{c}\text { Respos } \\
\text { exper } \\
1 \quad 2\end{array}$ & $\begin{array}{l}\text { ise* } \\
\text { iment } \\
3\end{array}$ & & $\begin{array}{c}\text { Mean } \\
\text { angular } \\
\text { response }\end{array}$ & $\begin{array}{c}\text { Response } \\
(\%)\end{array}$ \\
\hline $\mathrm{S}+$ bovine serum albumin & 11 & 0 & 2 & $72 \cdot 5$ & $10 \cdot 0$ \\
\hline $\begin{array}{l}\mathrm{S}+\text { dialysable serum }+ \text { bovine serum } \\
\text { albumin }\end{array}$ & $\begin{array}{ll}0 & 0\end{array}$ & 0 & 2 & $53 \cdot 9$ & $5 \cdot 0$ \\
\hline $\mathbf{S}+$ non-dialysable serum & 43 & 3 & 7 & $162 \cdot 4$ & $42 \cdot 5$ \\
\hline $\mathbf{S}+$ whole serum & 13 & 2 & 2 & $104 \cdot 8$ & $20 \cdot 0$ \\
\hline
\end{tabular}

For S medium, see text. Oocytes were matured and fertilized with surrounding cumulus cells. Whole serum and serum fractions were added to media at $15 \%$ concentration, and bovine serum albumin was added at a concentration of $30 \mathrm{mg} / \mathrm{ml}$.

* Number of two-cell embryos out of a total of ten immature oocytes initially placed in culture.

\section{DISCUSSION}

In the present study, we found that cumulus cells do not significantly improve either (1) physiological oocyte maturation in vitro or (2) the fertilization in vitro of oocytes matured in vitro. The absence of an effect of cumulus cells matured in vitro on fertilization in vitro contrasts with the previously reported positive effect of cumulus cells matured in vivo on fertilization in vitro (Cross \& Brinster, 1970; Pavlok \& McLaren, 1972; Miyamoto \& Chang, 1972). This difference between cumulus cells matured in vivo versus in vitro suggests that these cells undergo an important change during maturation in vivo which renders them competent to contribute to normal oocyte development; cumulus cells not exposed to the in-vivo stimulus would not be able to function as well in either maturation or fertilization in vitro.

In addition to studying the rôle of cumulus cells in oocyte development, we also confirmed our previous finding that serum is beneficial to oocyte maturation in vitro (Cross \& Brinster, 1970) and we further demonstrated that the nondialysable fraction contains the component(s) which are responsible for the positive effect of serum. The dialysable fraction of serum was not only ineffective in supporting oocyte maturation but was inhibitory to development. The addition of albumin to defined media in this study did not substitute for serum 
and therefore serum must contribute more to oocyte development than just a protein polymer.

\section{ACKNOWLEDGMENTS}

I wish to thank Mrs Marian M. Kelley for her excellent technical assistance. This study was supported by NIH Contract 70-2150.

\section{REFERENCES}

Biggers, J. D. \& BrInster, R. L. (1965) Biometrical problems in the study of early mammalian embryos in vitro. F. exp. Zool. 158, 39.

BRINSTER, R. L. (1963) A method for in vitro cultivation of mouse ova from two-cell to blastocyst. Expl Cell Res. 32, 205.

CRoss, P. C. \& Brinster, R. L. (1970) In vitro development of mouse oocytes. Biol. Reprod. 3, 298.

Donakue, R. P. (1968) Maturation of the mouse oocyte in vitro. I. Sequence and timing of nuclear progression. F. exp. Zool. 169, 237.

Merchant, H. \& Ghang, M. C. (1971) An electron microscopic study of mouse eggs matured in vivo and in vitro. Anat. Rec. 171, 21.

Mryamoto, H. \& Ghang, M. C. (1972) Fertilization in vitro of mouse and hamster eggs after the removal of follicular cells. F. Reprod. Fert. 30, 309.

Pavlok, A. \& McLaren, A. (1972) The rôle of cumulus cells and the zona pellucida in fertilization of mouse eggs in vitro. F. Reprod. Fert. 29, 91.

SNedecor, G. W. (1956) Statistical methods, 5th edn. The Iowa State College Press, Ames, Iowa.

Whittingham, D. G. (1968) Fertilization of mouse eggs in vitro. Nature, Lond. 220, 592. 